\title{
Pengaruh Profitabilitas Terhadap Kebijakan Dividen Dengan Likuiditas Sebagai Pemoderasi
}

(Studi Empiris pada Sektor Pertanian yang Terdaftar di Bursa Efek Indonesia 2013-2017)

\author{
Zarah Puspitaningtyas, \\ Aryo Prakoso, \\ Andaratul Masruroh. \\ Fakultas Ilmu Sosial dan Ilmu Politik, Universitas Jember \\ E-mail:zarah@unej.ac.id
}

\begin{abstract}
The purpose of this study was to analyze the effect of profitability on dividend policy by using liquidity as a moderating variable. Profitability is proxied using asset returns, the dividend policy is proxied using a dividend payout ratio, while liquidity is proxied using the current ratio. This research uses quantitative with the type of association research. The population is all 21 companies in the agricultural sector listed on the Indonesia Stock Exchange, then the sample was selected using a purposive sampling method and obtained 7 companies. Data is obtained from the annual report on the official website of the Indonesia Stock Exchange. The next data collected was analyzed using the moderated regression analysis. The results of the analysis prove that profitability influences dividend policy and liquidity moderate the relationship of profitability with dividend policy.
\end{abstract}

Keyword: dividend policy, profitability, liquidity.

\section{ABSTRAK}

Tujuan studi ini adalah menganalisis pengaruh profitabilitas terhadap kebijakan dividen dengan menggunakan likuiditas sebagai variabel moderasi. Profitabilitas diproksikan menggunakan return on assets, kebijakan dividen diproksikan menggunakan dividend payout ratio, sedangkan likuiditas diproksikan dengan menggunakan current ratio. Studi ini dianalisis menggunakan pendekatan kuantitatif dengan jenis penelitian asosiasi. Populasi adalah seluruh perusahaan sektor pertanian yang terdaftar di Bursa Efek Indonesia sebanyak 21 perusahaan, selanjutnya sampel dipilih menggunakan metode purposive sampling dan diperoleh 7 perusahaan. Data diperoleh dari laporan tahunan pada website resmi Bursa Efek Indonesia. Selanjutnya data yang terkumpul dianalisis menggunakan moderated regression analisys. Hasil analisis membuktikan bahwa profitabilitas berpengaruh terhadap kebijakan dividen dan likuiditas memoderasi hubungan profitabilitas dengan kebijakan dividen.

Kata kunci: kebijakan dividen, profitabilitas, likuiditas

\section{PENDAHULUAN}

Perekonomian dunia saat ini berkembang dengan pesat (Noor Hasan, 2014). Perusahaan sebagai suatu organisasi bisnis memiliki tujuan utama yaitu mensejahterakan para pemegang saham (Syafrida \& Nurhayati, 2015). Tujuan tersebut, tercermin pada kebijakan dividen perusahaan. Kebijakan dividen dilakukan guna menentukan besarnya bagian 
pendapatan yang dibagikan kepada pemegang saham dan bagian yang akan ditahan oleh perusahaan (Nafi'ah, 2011). Bagi investor pembayaran dividen yang stabil merupakan indikator prospek suatu perusahaan yang stabil pula, dengan demikian risiko perusahaan juga relatif rendah dibandingkan dengan perusahaan yang membayarkan dividen tidak stabil (Sartono, 2001).

Perusahaan dengan tingkat profitabilitas yang tinggi akan menarik minat investor untuk berinvestasi pada saham perusahaan (Adipalguna \& Suarjaya, 2017). Profitabilitas diperlukan pada saat perusahaan akan membagikan dividennya. Pihak manajemen perusahaan akan membayarkan dividen untuk memberi sinyal kepada pemegang saham mengenai tingkat keberhasilan perusahaan dalam memperoleh profit (Wirjolukito, A. Yanto, \& Sandy, 2003). Sinyal yang diciptakan oleh profitabilitas menunjukkan kemampuan suatu perusahaan dalam membayar dividen bagi pemegang saham.

Dalam studi ini, likuiditas digunakan sebagai variabel moderasi yang akan menguji kemampuannya dalam memperkuat atau memperlemah hubungan antara profitabilitas dan kebijakan dividen (Setiawan, Nur, \& Yuyetta, 2013). Likuiditas diartikan sebagai kemampuan perusahaan dalam melunasi hutang jangka pendeknya. Apabila suatu perusahaan mempunyai profitabilitas yang tinggi dan didukung dengan likuiditas yang baik maka diharapkan akan memperbesar pembayaran dividen (Suharli, 2007).

Pertumbuhan sektor pertanian ekonomi triwulan II 2018 menyatakan kontribusi pertanian pada laju pertumbuhan produk domestik bruto (PDB) mencapai 13,63 persen dan terjadinya peningkatan produktivitas tenaga kerja sektor pertanian sehingga layak untuk menjadi pertimbangan investor untuk berinvestasi. Sektor pertanian memiliki pertumbuhan yang fluktuatif, pada tahun 2013 terjadi pertumbuhan 3,44 persen dan meningkatkan kembali pada tahun 2014 menjadi 4,24 persen (Kementerian Perindustrian Republik Indonesia, 2018). Namun, pada periode 2015 dan 2016 mengalami penurunan pertumbuhan sebesar 3,75 persen dan 3,36 persen. Pada tahun 2017, sektor pertanian meningkat kembali menjadi 3,81 persen. Pertumbuhan tersebut juga mempengaruhi pembagian dividen yang juga berfluktuasi. Berdasarkan laporan tahunan perusahaan terdapat perusahaan sektor pertanian yang membagikan dividen ketika perusahaan sedang mengalami kerugian dan hal tersebut layak diteliti dikarenakan kebijakan yang diambil oleh pihak manajemen perusahaan tidak sesuai dengan 
teori sinyal. Pembagian dividen seharusnya mencerminkan profitabilitas yang diperoleh perusahaan (Dewi \& Sedana, 2018).

Berdasarkan beberapa temuan studi terdahulu masih terjadi inkonsistensi atau adanya keberagaman hasil penelitian. Suharli (2007) membuktikan bahwa kebijakan jumlah pembagian dividen perusahan dipengaruhi oleh profitabilitas. Suwarti (2010) membuktikan bahwa profitabilitas tidak berpengaruh terhadap kebijakan dividen dan likuiditas tidak memperkuat hubungan keduanya. Rahmiyati \& Rahim (2013) membuktikan bahwa likuiditas memperlemah hubungan profitabilitas dan kebijakan dividen. Fistyarini \& Kusmuriyanto (2015) membuktikan bahwa profitabilitas mempengaruhi kebijakan dividen tunai secara positif signifikan dan likuiditas memperkuat hubungan profitabilitas dan kebijakan dividen tunai. Simarmata \& Hutajulu (2017) membuktikan bahwa likuiditas tidak dapat memoderasi hubungan antara profitabilitas dan kebijakan dividen.

Berdasarkan latar belakang tersebut, tujuan studi ini adalah menguji dan menganalisis pengaruh profitabilitas terhadap kebijakan dividen dengan menggunakan likuiditas sebagai variabel moderasi. Profitabilitas diproksikan menggunakan return on assets (ROA), kebijakan dividen diproksikan menggunakan dividend payout ratio (DPR), dan likuiditas diproksikan menggunakan current ratio $(\mathrm{CR})$.

\section{TINJAUAN PUSTAKA}

\section{Teori Sinyal}

Signalling theory (Dewi \& Wiratmaja, 2017), bahwasanya sebuah informasi memiliki nilai, dan di dalam suatu transaksi para pihak yang terlibat memiliki tingkat informasi yang berbedabeda. Pemegang saham akan lebih cenderung memilih suatu perusahaan dengan prospek yang lebih menguntungkan (Brigham \& Houston, 2013), untuk menghindari penjualan saham karena apabila pada suatu perusahaan yang memiliki prospek yang tidak menguntungkan maka perusahaan tersebut akan melakukan pendanaan menggunakan saham, dimana artinya membawa pemegang saham untuk berbagi kerugian. Pihak manajemen akan membagikan dividen kepada pemegang saham sebagai sinyal mengenai keberhasilannya dalam membukukan profit (Wirjolukito, A. Yanto, \& Sandy, 2003).

Untuk mendapatkan informasi yang lengkap, relevan, akurat dan tepat waktu sangat dibutuhkan oleh investor di pasar modal sebagai alat analisis dalam mengambil keputusan investasi (Jogiyanto, 
2000). Perusahaan akan melaporkan secara sukarela atas laporan keuangannya ke pasar modal untuk menarik investor menginvestasikan dananya, kemudian manajer akan memberikan sinyal dengan menyajikan laporan keuangan yang baik dalam membukukan profitnya.

\section{Pasar Modal}

Pasar modal merupakan tempat pertemuan antara penawaran dan permintaan atas surat berharga (Muharram, 2018). Pasar modal disebut juga sebagai tempat bertemunya penjual dan pembeli modal atau dana (Santoso, 2017). Pasar modal merupakan penghubung antara investor (pihak yang memiliki dana) dengan perusahaan (pihak yang memerlukan dana) ataupun institusi pemerintah melalui perdagangan instrument (Alamsyah Hasan \& Enni, 2015). Pasar modal juga menjadi salah satu cara perusahaan dalam mencari dana dengan menjual hak kepemilikan perusahan kepada investor (Sholichah, 2015). Tempat dimana individu atau badan usaha yang memiliki kelebihan dana melakukan investasi berupa surat berharga yang ditawarkan oleh emiten (Fahmi, 2015). Keuntungan melakukan investasi di pasar modal yaitu investor dapat memperoleh dividen atas keuntungan yang diperoleh perusahaan atas saham yang dimilikinya (Hanim, Dzulkirom, \& Topowijono, 2015).

\section{Kebijakan Dividen}

Dividen (Suharli, 2007; Zakiyah, 2017; Alistraja D. Silalahi, 2018) adalah bagian dari laba yang dibagikan kepada pemegang saham perusahaan sebanding dengan jumlah saham yang dimiliki oleh masing-masing pemilik. Dividen yang dibagikan dapat berupa dividen tunai maupun dividen saham. Ikatan Akuntan Indonesia (2004) dalam PSAK No. 23 merumuskan dividen sebagai distribusi laba yang diberikan kepada pemegang saham harus sesuai dengan proporsi mereka dari jenis model tertentu.

Kebijakan dividen adalah suatu keputusan mengenai laba yang diperoleh perusahaan dan akan dibagikan kepada pemegang saham sebagai dividen atau akan ditahan sebagai laba ditahan guna pembiayaan investasi di masa yang akan datang (Setiawan et al., 2013). Apabila perusahaan memilih untuk membagikan laba sebagai dividen maka kebijakan ini akan mengurangi laba yang ditahan dan mengurangi dana intern (Widayati, 2008). Sebaliknya, jika memilih untuk menahan laba yang diperoleh maka kemampuan pembentukan dana intern akan semakin besar.

\section{Profitabilitas}

Profitabilitas adalah sesuatu yang diperoleh perusahaan di atas biaya-biaya yang telah dikeluarkan (Ahmad, 2009). 
Profitabilitas berkaitan dengan laba, laba inilah yang akan digunakan sebagai dasar dalam pembagian dividen. Profitabilitas ini diperlukan saat perusahaan akan melakukan pembagian dividen. Semakin besar profitabilitas yang diperoleh perusahaan maka akan akan semakin besar pula dividen yang akan diperoleh oleh pemegang saham.

Profitabilitas perusahaan merupakan variabel yang cukup penting saat perusahaan memutuskan akan melakukan distribusi dividen kepada pemegang saham atau digunakan sebagai laba ditahan oleh perusahaan ataupun laba yang diperoleh perusahaan tersebut digunakan untuk investasi dengan harapan perusahaan akan memperoleh keuntungan di masa yang akan datang (Gryglewicz, 2010; Putra \& Lestari, 2016).

\section{Likuiditas}

Menurut Sartono (2001), likuiditas merupakan pertimbangan utama dalam kegiatan kebijakan dividen. Likuiditas adalah kemampuan suatu perusahaan dalam membayar kewajiban jangka pendek ataupun kewajiban yang akan segera jatuh tempo. Perusahaan yang dapat membayar semua hutang jangka pendeknya dikatakan sebagai perusahaan yang liquid. Perusahaan yang memiliki likuiditas yang lebih baik maka diprediksi akan mampu membayarkan dividen lebih banyak (Suharli, 2007).

\section{Hubungan Profitabilitas dan Kebijakan Dividen}

Profitabilitas merupakan kemampuan suatu perusahaan dalam memperoleh laba atau keuntungan (Suryono, 2016). Semakin tinggi profitabilitas suatu perusahaan artinya semakin baik, karena kemakmuran pemilik perusahaan meningkat dengan semakin meningkatnya profitabilitas (Prakoso, 2016). Pembayaran dividen dilakukan pada saat perusahaan memperoleh laba yang tinggi (Pontoh, 2014). Sehingga profitabilitas memiliki pengaruh dalam pembagian dividen kepada pemegang saham (Hanim et al., 2015; Setiawan et al., 2013). Semakin tinggi profitabilitas yang diperoleh perusahaan maka akan semakin tinggi pula dividen yang akan diperoleh pemegang saham (Agustina \& Andayani, 2016; Mayogi \& Fidiana, 2016; Setiawan et al., 2013; Zakiyah, 2017). Sebaliknya, semakin rendah profitabilitas perusahaan maka pembagian dividen akan rendah atau tidak adanya pembagian dividen (Agustina \& Andayani, 2016; Ishaq \& Asyik, 2015). Jadi, pihak manajemen perusahaan akan berusaha memperoleh laba sebesarbesarnya untuk meningkatkan kemampuan membayar dividen (Darminto, 2008). Teori sinyal menjelaskan bahwa pihak manajemen perusahaan akan memberi sinyal kepada investor dengan membagikan 
dividen yang menunjukkan keberhasilan perusahaan dalam memperoleh profit. Jadi, dengan adanya profitabilitas yang tinggi diharapkan perusahaan dapat membagikan dividen, sehingga kemampuan perusahaan dalam membagikan dividen tersebut menjadi fungsi dari keuntungan perusahaan (Fistyarini \& Kusmuriyanto, 2015).

\section{Hubungan Profitabilitas dan Kebijakan}

Dividen dengan Likuiditas sebagai

\section{Variabel Moderasi}

Likuiditas merupakan kemampuan perusahaan dalam memenuhi kewajiban jangka pendeknya, termasuk melunasi hutang dan membayar dividen kepada pemegang saham. Likuiditas suatu perusahaan bisa saja buruk meskipun perusahaan mampu memperoleh laba bersih setelah pajak dan memiliki laba ditahan yang besar (Istikomah, 2014). Hal ini dikarenakan perusahaan cenderung menginvestasikan laba yang diperoleh ke harta tetap yang menyebabkan perusahaan tidak membagikan dividen kepada pemegang sahamnya. Apabila perusahaan memiliki keuntungan yang lebih tinggi ditambah likuiditas yang lebih baik, maka semakin besar jumlah dividen yang akan dibagikan. Apabila perusahaan menginvestasikan dana lebih banyak maka akan menyebabkan jumlah dividen yang dibayarkan cenderung berkurang, sehingga likuiditas yang baik mampu memperlemah hipotesis karena perusahaan dapat menunda pembayaran hutang jangka pendek (Suharli, 2007).

Dividen akan semakin besar apabila tingkat likuiditas perusahaan semakin tinggi, karena dividen merupakan arus kas perusahaan (Andini, 2018). Kas yang memadai belum tentu dimiliki oleh perusahaan dengan laba tinggi, sehingga jika perusahaan ingin membagikan dividen maka diperlukan kas yang cukup karena dividen pada umumnya dibagikan dalam bentuk dividen kas (Darminto, 2008). Perusahaan yang memiliki tingkat profitabilitas tinggi serta likuiditas yang baik, maka dividen yang akan dibagikan juga semakin besar (Suharli, 2007). Studi oleh Suwarti (2010), Fistyarini \& Kusmuriyanto (2015) membuktikan bahwa profitabilitas berpengaruh positif terhadap kebijakan dividen dan likuiditas memperkuat pengaruh profitabilitas terhadap kebijakan dividen.

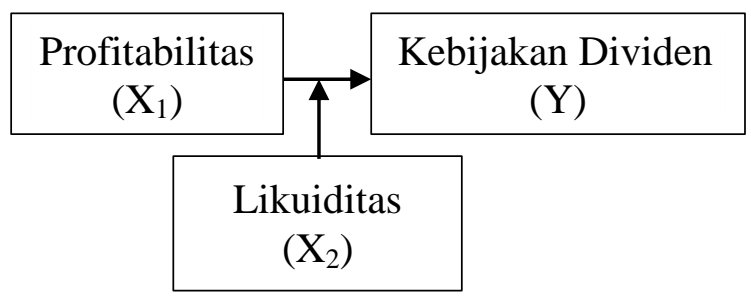

Gambar 1. Kerangka Konseptual

\section{Hipotesis}

$\mathrm{H}_{1}=$ Profitabilitas berpengaruh terhadap kebijakan dividen pada perusahaan sektor pertanian. 


\section{$\mathrm{H}_{2}=$ Likuiditas memoderasi pengaruh profitabilitas terhadap kebijakan dividen pada perusahaan sektor pertanian.}

\section{METODE PENELITIAN}

\section{Populasi dan Sampel}

Sugiyono (2014) mengemukakan bahwa populasi merupakan wilayah secara umum yang terdiri atas objek-objek yang memiliki kualitas dan karakteristik tertentu yang ditetapkan oleh peneliti untuk dipelajari dan kemudian ditarik kesimpulannya. Populasi dalam studi ini adalah 21 perusahaan sektor pertanian yang terdaftar di Bursa Efek Indonesia dengan periode pengamatan tahun 2013 - 2017. Selanjutnya, berdasarkan teknik purposive sampling diperoleh 7 perusahaan sektor pertanian yang terdaftar di Bursa Efek Indonesia sebagai sampel studi.

\section{Jenis dan Sumber Data}

Sumber data sekunder yaitu data yang dikumpulkan dari tangan kedua atau dari sumber-sumber lain yang telah tersedia sebelum penelitian dilakukan (Silalahi, 2017). Data yang digunakan dalam studi ini adalah data sekunder dengan menggunakan laporan keuangan tahunan yang terdaftar di Bursa Efek Indonesia (BEI) yang tercatat dalam situs www.idx.co.id selama periode pengamatan tahun 2013-2017.

\section{Definisi Operasional Variabel dan Skala Pengukurannya}

\section{a. Variabel Dependen}

Variabel dependen merupakan variabel yang dipengaruhi oleh variabel independen. Oleh karena itu, variabel dependen atau terikat bergantung pada variabel independen atau bebas dan merupakan hasil dari pengaruh variabel bebas (Silalahi, 2017). Puspitaningtyas mengemukakan bahwa kebijakan dividen dapat tercermin dari pengukuran rasio pembayaran dividen (dividend payout ratio).

Rumus dividend payout ratio dalam studi ini adalah sebagai berikut:

$D P R=\frac{\text { Dividen per lembar saham }}{\text { Laba per lembar saham }} \times 100 \%$

\section{b. Variabel Independen}

Variabel independen atau variabel bebas merupakan variabel yang menjadi sebab perubahan atau timbulnya variabel terikat (Sugiyono, 2015). Variabel independen dalam studi ini adalah profitabilitas yang diukur dengan return on assets (ROA). ROA adalah rasio yang menggambarkan kemampuan perusahaan menghasilkan laba atas aset yang dimiliki. Rumus return on assets dalam studi ini adalah sebagai berikut:

$$
R O A=\frac{\text { Laba bersih setelah pajak }}{\text { Total aset }} X 100 \%
$$




\section{c. Variabel Moderasi}

Variabel moderasi merupakan variabel yang memengaruhi baik memperkuat atau memperlemah hubungan antara variabel independen dan variabel dependen (Sugiyono, 2014). Variabel moderasi dalam penelitian ini adalah likuiditas. Likuiditas diukur dengan menggunakan current ratio. Current ratio merupakan ukuran perusahaan dalam mengetahui kemampuan perusahaan memenuhi kewajibannya.

Rumus current ratio dalam studi ini adalah sebagai berikut:

$$
C R=\frac{\text { Aktiva lancar }}{\text { Hutang lancar }} X 100 \%
$$

\section{Metode Analisis Data dan Pengujian}

\section{Hipotesis}

Data yang terkumpul selanjutnya dianalisis menggunakan moderated regression analysis. Sebelum moderated regression analysis dilakukan, terlebih dahulu dilakukan tahapan uji statistik deskriptif dan uji asumsi klasik (uji normalitas, uji multikolinieritas, uji autokorelasi, dan uji heteroskedastisitas).

\section{HASIL DAN PEMBAHASAN}

\section{a. Statistik Deskriptif}

Statistik deskriptif digunakan untuk menganalisis data dengan cara mendeskripsikan atau menggambarkan data yang telah terkumpul sebagaimana adanya (Sugiyono, 2014). Syarat data penelitian dikatakan baik apabila nilai mean di atas nilai minimum dan standar deviasinya mendekati nilai mean. Hasil statistik deskriptif adalah sebagai berikut:

Tabel 1. Hasil statistik deskriptif

\begin{tabular}{lccccc}
\hline \multicolumn{1}{c}{$\begin{array}{c}\text { Variabel } \\
\text { Penelitian }\end{array}$} & N & Min & Max & Mean & $\begin{array}{c}\text { Standar } \\
\text { Deviasi }\end{array}$ \\
\hline $\begin{array}{l}\text { Profitabilitas } \\
\left(\mathrm{X}_{1}\right)\end{array}$ & 35 & 1,15 & 18,29 & 6,83 & 4,4378 \\
Likuiditas (X $)$ & 35 & 80,15 & 763,24 & 239,23 & 210,8734 \\
$\begin{array}{l}\text { Kebijakan } \\
\text { Dividen (Y) }\end{array}$ & 35 & 10,29 & 78,75 & 31,54 & 14,1088 \\
\hline
\end{tabular}

Sumber: data diolah, 2019

Berdasarkan tabel 1 diketahui bahwa variabel profitabilitas menunjukkan nilai rata-rata (mean) sebesar 6,83. Nilai terendah variabel profitabilitas sebesar 1,15 dan nilai tertinggi 18,29. Standar deviasi sebesar 4,4378. Variabel likuiditas menunjukkan nilai rata-rata (mean) sebesar 239,23. Nilai terendah variabel likuiditas sebesar 80,15 dan nilai tertinggi 763,24. Standar deviasi sebesar 239,23. Selanjutnya, variabel kebijakan dividen menunjukkan nilai rata-rata (mean) sebesar 31,54. Nilai terendah variabel kebijakan dividen sebesar 10,29 dan nilai tertinggi 78,75. Standar deviasi sebesar 14,1088. Hasil uji statistik deskriptif menunjukkan bahwa nilai standar deviasi yang mendekati nilai rata-rata (mean) dan ukuran penyebaran data yang semakin kecil.

\section{b. Uji Asumsi Klasik}

1) Uji Normalitas

Uji normalitas bertujuan untuk menguji apakah dalam sebuah model regresi, variabel pengganggu memiliki 
distribusi normal (Ghozali, 2011). Studi ini akan menggunakan uji one sample kolmogrov-smirnov dengan menggunakan taraf signifikansi 0,05. Data dinyatakan berdistribusi normal jika signifikansi lebih besar dari 0,05. Hasil uji normalitas adalah sebagai berikut.

Tabel 2. Hasil uji normalitas

\begin{tabular}{lcc}
\hline Variabel & $\begin{array}{c}\text { Nilai } \\
\text { Kolmogrov } \\
\text { Smirnov }\end{array}$ & Keterangan \\
\hline $\begin{array}{l}\text { Unstandarized } \\
\text { residual }\end{array}$ & 0,200 & $\begin{array}{c}\text { Berdistribusi } \\
\text { Normal }\end{array}$ \\
\hline Sumber: data diolah, 2019 & \\
Berdasarkan hasil uji & normalitas
\end{tabular}
pada tabel tersebut, diketahui bahwa nilai probabilitas atau signifikansi adalah 0,200. Nilai kolmogrov-smirnov 0,200 lebih besar dari 0,05 sehingga, dapat dinyatakan bahwa data dalam studi ini berdistribusi normal.

\section{2) Uji Multikolinieritas}

Ghozali (2011) mengemukakan bahwa uji multikolinearitas digunakan untuk mengetahui ada atau tidaknya korelasi antar variabel independen dalam model regresi. Cara mendeteksi multikolinieritas dapat melihat nilai tolerance dan varian inflation factor (VIF) sebagai tolak ukur. Nilai tolerance $\leq 0,10$ dan nilai VIF $\geq 10$ menunjukkan bahwa dalam penelitian tersebut terdapat multikolinieritas. Hasil uji multikolinearitas sebagai berikut.

\begin{tabular}{|c|c|c|c|}
\hline \multirow{2}{*}{ Model } & \multicolumn{2}{|c|}{ Collinearity Statistics } & \multirow{2}{*}{ Keterangan } \\
\hline & Tolerance & VIF & \\
\hline $\begin{array}{l}\text { Profitabilitas } \\
\left(\mathrm{X}_{1}\right)\end{array}$ & 0,522 & 1,917 & $\begin{array}{c}\text { tidak terjadi } \\
\text { multikolinieritas }\end{array}$ \\
\hline Likuiditas $\left(\mathrm{X}_{2}\right)$ & 0,330 & 3,031 & $\begin{array}{c}\text { tidak terjadi } \\
\text { multikolinieritas }\end{array}$ \\
\hline $\begin{array}{l}\text { Profitabilitas } \times \\
\text { Likuiditas }\left(\mathrm{X}_{3}\right) \\
\end{array}$ & 0,269 & 3,721 & $\begin{array}{c}\text { tidak terjadi } \\
\text { multikolinieritas }\end{array}$ \\
\hline
\end{tabular}

Berdasarkan hasil uji multikolinieritas diperoleh collinearity statistics profitabilitas dengan nilai tolerance 0,522 dan VIF sebesar 1.917. Likuiditas dengan nilai tolerance 0,330 dan VIF sebesar 3,031. Hasil profitabilitas $\times$ likuiditas yaitu nilai tolerance 0,269 dan VIF 3,721 yang dapat dilihat pada tabel 3 . Berdasarkan hasil tersebut, diketahui bahwa pada studi ini tidak terjadi multikolinieritas dibuktikan dengan nilai VIF dari masing-masing variabel kurang dari 10 dan nilai tolerance lebih dari 0,10.

\section{3) Uji Autokorelasi}

Uji autokolerasi bertujuan menguji apakah dalam model regresi linear ada kolerasi antara kesalahan pengganggu pada periode $\mathrm{t}$ dengan kesalahan pengganggu pada periode t-1 (sebelumnya) (Ghozali, 2011). Hasil uji autokorelasi sebagai berikut.

Tabel 4. Hasil uji autokorelasi

\begin{tabular}{cccc}
\hline $\begin{array}{c}\text { Nilai } \\
\text { DU }\end{array}$ & $\begin{array}{c}\text { Nilai Durbin } \\
\text { Watson }\end{array}$ & Nilai 4-DU & Keterangan \\
\hline 1,583 & 1,918 & 2,417 & $\begin{array}{c}\text { Tidak terjadi } \\
\text { autokorelasi }\end{array}$ \\
\hline
\end{tabular}

Sumber: data diolah, 2019 
Berdasarkan tabel 4, diketahui bahwa nilai durbin watson sebesar 1,918. Nilai DU pada studi ini sebesar 1,583. Nilai 4-DU diperoleh dari $4-1,583=2,417$. Nilai durbin watson berada diantara nilai DU dan 4-DU. Hasil uji ini menunjukkan bahwa data dalam studi ini tidak terjadi autokorelasi.

\section{4) Uji Heteroskedastisitas}

Uji heteroskedastisitas bertujuan untuk menguji apakah dalam model regresi terjadi ketidaksamaan variance dari residual suatu pengamatan ke pengamatan lain. Untuk mendeteksi terjadinya heteroskedastisitas dalam studi ini maka digunakan uji glejser. Uji glejser dilakukan dengan meregresikan variabel-variabel bebas terhadap nilai absolut residualnya (Gujarati, 2003). Nilai signifikansi yang lebih besar dari $\alpha=5 \%$, maka membuktikan tidak terjadi gejala heteroskedastisitas. Hasil uji heteroskedastisitas sebagai berikut.

Tabel 5. Hasil uji glejser

\begin{tabular}{|c|c|c|}
\hline Variabel & Sig & Keterangan \\
\hline Profitabilitas $\left(\mathrm{X}_{1}\right)$ & 0,499 & $\begin{array}{c}\text { Tidak terjadi } \\
\text { heterokesdatisitas }\end{array}$ \\
\hline Likuiditas $\left(\mathrm{X}_{2}\right)$ & 0,961 & $\begin{array}{c}\text { Tidak terjadi } \\
\text { heterokesdatisitas }\end{array}$ \\
\hline $\begin{array}{l}\text { Profitabilitas } \times \text { Likuiditas } \\
\left(\mathrm{X}_{3}\right)\end{array}$ & 0,308 & $\begin{array}{c}\text { Tidak terjadi } \\
\text { heterokesdatisitas }\end{array}$ \\
\hline
\end{tabular}

Sumber: data diolah, 2019

Berdasarkan uji heterokesdatisitas pada tabel 5 diperoleh nilai profitabilitas 0,499, likuiditas 0,961 dan profitabilitas $\times$ likuiditas sebesar 0,308 dapat diketahui bahwa nilai signifikansi masing-masing variabel lebih besar dari 0,05, sehingga dari hasil tersebut membuktikan bahwa tidak terjadi heterokesdatisitas dari persamaan yang diuji.

Syarat untuk pengujian hipotesis dengan menggunakan model regresi adalah pengujian asumsi klasik. Jika asumsiasumsi tersebut tidak terpenuhi secara keseluruhan maka hasilnya akan bias (Gujarati, 2003). Berdasarkan hasil uji normalitas membuktikan data berdistribusi normal, tidak terjadi multikolinieritas, tidak terjadi autokorelasi dan tidak terjadi heteroskedastisitas. Berdasarkan hasil uji asumsi klasik maka model yang digunakan untuk analisis dalam studi ini memenuhi asumsi best, linear, unbias, dan estimated.

\section{c. Moderated Regression Analysis}

Moderated regression analysis (MRA) atau uji interaksi merupakan suatu aplikasi khusus regresi linear dimana dalam regresinya mengandung unsur interaksi (perkalian dua atau lebih variabel independen) (Ghozali, 2011). Hasil moderated regression analysis terhadap hipotesis studi ini dapat dilihat pada tabel 6 sebagai berikut.

Tabel 6. Hasil moderated regression analysis (MRA)

\begin{tabular}{lccc}
\hline \multicolumn{1}{c}{ Variabel } & $\begin{array}{l}\text { Koefisien } \\
\text { Regresi }\end{array}$ & Sig. & Keterangan \\
\hline Konstanta & 0,020 & - & - \\
Profitabilitas $\left(\mathrm{X}_{1}\right)$ & 0,286 & 0,018 & Signifikan \\
\hline
\end{tabular}




\begin{tabular}{llll}
\hline Likuiditas $\left(\mathrm{X}_{2}\right)$ & 0,401 & 0,041 & Signifikan \\
Profitabilitas $\times$ & 0,348 & 0,035 & Signifikan \\
Likuiditas $\left(\mathrm{X}_{1} \cdot \mathrm{X}_{2}\right)$ & & \\
\hline
\end{tabular}

Sumber: data diolah, 2019

Persamaan regresi yang diperoleh dari

pengujian tersebut adalah:

$\mathrm{Y}=0,020+0,286 \mathrm{X}_{1}+0,401 \mathrm{X}_{2}+0,348 \mathrm{X}_{1} \cdot \mathrm{X}_{2}+$ e

Hasil moderated regression analysis dijelaskan sebagai berikut:

1. Konstanta dalam persamaan regresi tersebut adalah 0,020 yang artinya, jika profitabilitas $\left(\mathrm{X}_{1}\right)$, likuiditas $\left(\mathrm{X}_{2}\right)$ dan profitabilitas $\times$ likuiditas $\left(\mathrm{X}_{1} \cdot \mathrm{X}_{2}\right)$, bernilai $0 \%$, maka kebijakan dividen (Y) sebesar $0,020 \%$.

2. Variabel profitabilitas memiliki nilai signifikansi sebesar 0,018. Nilai koefisien regresi variabel profitabilitas $\left(\mathrm{X}_{1}\right)$ sebesar 0,286 yang artinya, jika terjadi peningkatan variabel profitabilitas $\left(\mathrm{X}_{1}\right)$ sebesar $1 \%$, maka nilai variabel kebijakan dividen (Y) akan mengalami peningkatan sebesar $0,286 \%$.

3. Variabel likuiditas $\left(\mathrm{X}_{2}\right)$ memiliki nilai signifikansi sebesar 0,041. Nilai koefisien regresi variabel likuiditas $\left(\mathrm{X}_{2}\right)$ sebesar 0,401 yang artinya, jika terjadi peningkatan variabel likuiditas $\left(\mathrm{X}_{2}\right)$ sebesar $1 \%$, maka nilai variabel kebijakan dividen (Y) akan mengalami peningkatan sebesar $0,401 \%$.

4. Variabel profitabilitas $\times$ likuiditas $\left(\mathrm{X}_{1} \cdot \mathrm{X}_{2}\right)$ memiliki nilai signifikansi sebesar 0,035. Nilai koefisien regresi profitabilitas $\times$ likuiditas $\left(\mathrm{X}_{1} \cdot \mathrm{X}_{2}\right)$ sebesar 0,348yang artinya, jika terjadi peningkatan variabel profitabilitas $\times$ likuiditas $\left(\mathrm{X}_{1} \mathrm{X}_{2}\right)$ sebesar $1 \%$, maka nilai variabel kebijakan dividen (Y) akan mengalami peningkatan sebesar $0,348 \%$.

\section{Pembahasan}

\section{Pengaruh Profitabilitas terhadap Kebijakan Dividen}

Hasil analisis moderated regression analysis (MRA) terhadap hipotesis pertama $\left(\mathrm{H}_{1}\right)$ membuktikan bahwa profitabilitas berpengaruh terhadap kebijakan dividen dengan melihat nilai signifikansinya yaitu sebesar 0,018 yang artinya semakin tinggi profitabilitas maka akan meningkatkan kebijakan dividen ( $\mathrm{H}_{1}$ diterima).

Profitabilitas adalah sesuatu yang diperoleh perusahaan di atas biaya-biaya yang telah dikeluarkan (Ahmad, 2009). Profitabilitas merupakan kemampuan suatu perusahaan dalam memperoleh laba atau keuntungan. Profitabilitas ini diperlukan saat perusahaan akan melakukan pembagian dividen. Semakin tinggi profitabilitas suatu perusahaan artinya semakin baik, karena kemakmuran pemilik perusahaan meningkat dengan semakin meningkatnya profitabilitas (Prakoso, 2016). Pembayaran dividen dilakukan pada saat perusahaan memperoleh laba yang 
tinggi. Profitabilitas memiliki pengaruh dalam pembagian dividen kepada pemegang saham. Semakin tinggi profitabilitas yang diperoleh perusahaan maka akan semakin tinggi pula dividen yang akan diperoleh pemegang saham. Semakin rendah profitabilitas perusahaan maka pembagian dividen akan rendah atau tidak adanya pembagian dividen. Pihak manajemen perusahaan akan berusaha memperoleh laba sebesar-besarnya untuk meningkatkan kemampuan membayar dividen (Darminto, 2008). Pihak manajemen akan membagikan dividen kepada pemegang saham sebagai sinyal mengenai keberhasilannya dalam membukukan profit (Wirjolukito, A. Yanto, \& Sandy, 2003). Ross dalam Simarmata \& Hutajulu (2017) mendefisikan dividen sebagai alat pembayaran kepada pemilik saham yang diambil dari keuntungan yang diperoleh dari laba perusahaan, baik dalam bentuk tunai maupun saham. Artinya, hanya perusahaan yang memperoleh laba yang dapat membagikan dividen kepada pemegang saham karena dividen diambil dari laba yang diperoleh perusahaan. Hasil studi ini mendukung hasil studi sebelumnya yang dilakukan oleh Suharli (2007), Suwarti (2010), Rahmiyati \& Rahim (2013), Fistyarini \& Kusmuriyanto (2015), serta Parmitasari \& Sutrisna (2016) yang membuktikan bahwa profitabilitas berpengaruh terhadap kebijakan dividen.

\section{Pengaruh Profitabilitas dan Kebijakan}

\section{Dividen dengan Likuiditas sebagai} Variabel Moderasi

$$
\text { Hasil moderated regression }
$$
analysis (MRA) terhadap hipotesis kedua $\left(\mathrm{H}_{2}\right)$ membuktikan bahwa likuiditas memoderasi hubungan profitabilitas terhadap kebijakan dividen dengan melihat nilai signifikansinya yaitu sebesar 0,035 yang artinya semakin tinggi likuiditas maka akan memperkuat pengaruh profitabilitas terhadap kebijakan dividen $\left(\mathrm{H}_{2}\right.$ diterima). Ross dalam Simarmata \& Hutajulu (2017) mendefisikan dividen sebagai alat pembayaran kepada pemilik saham yang diambil dari keuntungan yang diperoleh dari laba perusahaan, baik dalam bentuk tunai maupun saham. Likuiditas merupakan pertimbangan utama dalam kegiatan kebijakan dividen (Sartono, 2001). Likuiditas adalah kemampuan perusahaan dalam memenuhi kewajiban jangka pendeknya, termasuk melunasi hutang dan membayar dividen kepada pemegang saham. Dividen akan semakin besar apabila tingkat likuiditas perusahaan semakin tinggi karena dividen merupakan arus kas perusahaan. Kas yang memadai belum tentu dimiliki oleh perusahaan dengan laba tinggi, sehingga jika perusahaan ingin 
membagikan dividen maka diperlukan kas yang cukup karena dividen pada umumnya dibagikan dalam bentuk dividen kas (Darminto, 2008). Perusahaan yang memiliki tingkat profitabilitas tinggi serta likuiditas yang baik, maka dividen yang akan dibagikan juga semakin besar (Suharli, 2007).

Budiyanto (2011) berpendapat bahwa administrasi adalah fungsi industri yang berkaitan dengan penetapan kebijakan perusahan, koordinasi produksi, keuangan dan distribusi, penentuan arah organisasi dan kontrol tertinggi eksekutif. Pendapat tersebut berkaitan dengan teori agency cost yang menjelaskan mengenai kepentingan manajemen dan kepentingan pemegang saham seringkali bertentangan (Jansen dan Meckling (1976) dalam Suwarti (2010)). Oleh karena itu, dividen dapat digunakan untuk memperkecil masalah keagenan yang timbul antara manajer dan pemegang saham (Suwarti, 2010). Dividen sebagai alat pembayaran kepada pemilik saham yang diambil dari keuntungan yang diperoleh dari laba perusahaan, dengan likuiditas sebagai pertimbangan utama dalam menentukan kebijakan dividen (Sartono, 2001). Hasil studi ini mendukung hasil studi sebelumnya yang dilakukan oleh Suharli (2007), Suwarti (2010), Fistyarini \& Kusmuriyanto (2015), serta Parmitasari \& Sutrisna (2016) yang membuktikan bahwa likuiditas memoderasi pengaruh profitabilitas terhadap kebijakan dividen.

\section{SIMPULAN}

Hasil pengujian moderated regression analysis (MRA) $\mathrm{H}_{1}$ atas pengaruh profitabilitas terhadap kebijakan dividen menunjukkan pengaruh yang signifikan, artinya semakin besar profitabilitas akan meningkatkan kebijakan dividen. Hasil uji studi ini mendukung signalling theory yang menyatakan bahwa pihak manajemen akan membayarkan dividen untuk memberikan sinyal bahwa perusahaan berhasil dalam membukukan profit. Hasil pengujian $\mathrm{H}_{2}$ atas likuiditas terbukti memperkuat pengaruh profitabilitas terhadap kebijakan dividen, artinya likuiditas yang tinggi akan memperkuat pengaruh profitabilitas terhadap kebijakan dividen. Hasil studi ini mengindikasikan bahwa apabila suatu perusahaan memiliki profitabilitas yang baik dan didukung likuiditas yang baik maka dividen yang diterima oleh pemegang saham diharapkan akan lebih besar. Berdasarkan hasil studi, peneliti memberi saran sebaiknya perusahaan sektor pertanian mampu menjaga nilai dari rasio keuangannya (baik ROA, CR maupun DPR) sehingga dapat bermanfaat bagi investor sebagai pertimbangan untuk 
menginvestasikan dananya dan untuk meningkatkan kepercayaan stakeholder.

\section{DAFTAR PUSTAKA}

Adipalguna, I., \& Suarjaya, A. (2017). Pengaruh Likuiditas, Solvabilitas, Aktivitas, Profitabilitas, dan Penilaian Pasar Terhadap Harga Saham Perusahaan LQ45 di BEI. E-Jurnal Manajemen Universitas Udayana.

Agustina, L., \& Andayani. (2016). Pengaruh Kinerja Keuangan, Ukuran Perusahaan, dan Pertumbuhan Perusahaan terhadap Kebijakan Dividen. Jurnal Ilmu Dan Riset Akuntansi.

Ahmad, R. (2009). Pengaruh Profitabilitas dan Investment Opportunity Set Terhadap Kebijakan Deviden Tunai. Jurnal Ilmiah Abdi Ilmu, 188-201.

Alamsyah Hasan, M., \& Enni, S. (2015). Studi Tentang Pengaruh Hari Perdagangan Terhadap Return Saham pada Bursa Efek Indonesia. Pekbis Jurnal.

Alistraja D. Silalahi, R. F. P. (2018). Peninjauan Kinerja Perusahaan Alat Berat yang Terdaftar di BEI Melalui Analisis Laporan Keuangan Ditinjau dari Rentabilitas dan Model ALTMAN Dalam Perspektif Islam (Syariah). Jurnal Penelitian Pendidikan Sosial Humaniora. https://doi.org/10.32696/jp2sh.v3i1.9 2

Andini, D. P. (2018). Kemampuan Prediksi Rasio-Rasio Keuangan Terhadap Laba dan Arus Kas Masa Depan dan Pengaruhnya Terhadap Divident Payout Ratio pada Perusahaan Manufaktur dan Jasa. Jurnal
Akuntansi Universitas Jember. https://doi.org/10.19184/jauj.v9i2.124 0

Brigham, E., \& Houston, J. (2013). Dasardasar Manajemen Keuangan. Jakarta: Salemba Empat.

Budiyanto, H. (2011). Administrasi Bisnis dan Manajemen. jurnal.unpand.ac.id., 1-11.

Darminto. (2008). Pengaruh Profitabilitas, Likuiditas, Struktur Modal dan Struktur Kepemilikan Saham Terhadap Kebijakan Dividen. Jurnal Ilmu-ilmu Sosial (Sosial Science), 8797.

Dewi, I. A. P. P., \& Sedana, I. B. P. (2018). Faktor-Faktor yang Mempengaruhi Kebijakan Dividen pada Perusahaan Manufaktur di Bursa Efek Indonesia. E-Jurnal Manajemen Universitas Udayana. https://doi.org/10.24843/ejmunud.201 8.v07.i07.p07

Dewi, W. P., \& Wiratmaja, I. D. (2017). Pengaruh Profitabilitas dan Solvabilitas pada Audit Delay dengan Ukuran Perusahaan Sebagai Variabel Pemoderasi. E-Jurnal Akuntansi Universitas Udayana, 409-437.

Fahmi, I. (2015). Manajemen Investasi: Teori dan Soal Jawab. Jakarta: Salemba Empat.

Fistyarini, R., \& Kusmuriyanto. (2015). Pengaruh Profitabilitas, IOS, dan Leverage Terhadap Kebijakan Dividen Tunai dengan dimoderasi Likuiditas. Accounting Analysis Journal, 1-8.

Ghozali, I. (2011). Aplikasi Analisis Multivariate dengan Progam SPSS. Semarang: Badan Penerbit 
Universitas Diponegoro.

Gryglewicz, S. (2010). A Theory of Corporate Financial Decision With Liquidity and Solvency Concerns. Journal of Financial Economics.

Gujarati, D. (2003). Basic Econometrics. Mc-Graw Hill. International Edition.

Hanim, S., Dzulkirom, M., \& Topowijono. (2015). Analisis Fundamental Saham Syariah dan Saham Konvensional Terhadap Kebijakan Pembayaran Dividen. Jurnal Administrasi Bisnis.

Ikatan Akuntan Indonesia. (2004). Standar Akuntansi Keuangan. Jakarta: Salemba Empat.

Ishaq, A. F., \& Asyik, N. F. (2015). Pengaruh Profitabilitas , Cash Position , Leverage , Dan Growth Terhadap Kebijakan Dividen. Jurnal Ilmu \& Riset Akuntansi.

Istikomah, N. (2014). Analisis Rasio Keuangan Untuk Menilai Kinerja Perusahaan Telekomunikasi Yang Terdaftar Di Bursa Efek Indonesia. Fakultas Ekonomi Dan Bisnis Universitas Brawijaya.

Jogiyanto. (2000). Teori Portofolio dan Analisis Investasi. Yogyakarta: BPFE UGM.

Kementerian Perindustrian Republik Indonesia. (2018). Sektor-Sektor Manufaktur Andalan Tahun 2018. Kementerian Perindustrian Republik Indonesia.

Mayogi, D. G., \& Fidiana. (2016). Pengaruh Profitabilitas, Kebijakan Deviden Dan Kebijakan Deviden Terhadap Nilai Perusahaan. Jurnal Ilmu Dan Riset Akuntansi.

Muharram, N. (2018). Perlindungan
Hukum Bagi Investor Dalam Pembelian Kembali Sahamnya. Jurnal Ilmu Hukum, 59-71.Nafi'ah, Z. (2011). Strategi Dan Stabilitas Pembayaran. Jurnal STIE Semarang.

Noor Hasan. (2014). Perancangan Aplikasi E-Commerce Penjualan Komputer. Bianglala Informatika.

Parmitasari, R. D., \& Sutrisna. (2016). Pengaruh Profitabilitas Terhadap Kebijakan Dividen Tunai dengan Likuiditas Sebagai Variabel Moderasi. Jurnal Manajemen Ide dan Inspirasi.

Pontoh, W. (2014). Laba Per Saham dan Ukuran: Karakteristik Pembayaran Dividen? Accountability. https://doi.org/10.32400/ja.4944.3.1.2 014.86-94

Prakoso, A. (2016). Pengaruh rasio CAMEL (Capital, Aset, Management, Equity, dan Liquidity) Terhadap Profitabilitas Bank (ROA) pada Perusahaan Perbankan Syariah yang Terdaftar di Bank Indonesia tahun 20013-2015. Jurnal Strategi dan Bisnis.

Puspitaningtyas, Z. (2017). Efek Moderasi Kebijakan Dividen Dalam Pengaruh Profitabilitas Terhadap Nilai Perusahaan Manufaktur. Jurnal Akuntansi, Ekonomi dan Manajemen Bisnis, 173-180.

Putra, A. D., \& Lestari, P. V. (2016). Pengaruh Kebijakan Dividen, Likuiditas, Profitabilitas dan Ukuran Perusahaan Terhadap Nilai Perusahaan. E-Jurnal Manajemen Unud, 4044-4070.

Rahmiyati, Y., \& Rahim, R. (2013). Pengaruh Profitabilitas dan Investment Opportunity Set (IOS) 
Terhadap Kebijakan Dividen dengan Likuiditas Sebagai Variabel Moderat.

Santoso, V. (2017). Akulturasi Estetika Sebagai Modal Untuk Menghadapi Pertukaran Kesenian dalam Masyarakat Ekonomi ASEAN (Sebuah Kajian Holistik Terhadap Perkembangan Kesenian Modern di Indonesia). Invensi. https://doi.org/10.24821/invensi.v1i1. 1604

Sartono, R. (2001). Manajemen Keuangan Teori dan Aplikasi. Yogyakarta: BPFE.

Sartono, A. (2001). Manajemen Keuangan Teori dan Aplikasi. Yogyakarta: BPFE.

Setiawan, Y., Nur, E., \& Yuyetta, A. (2013). Pengaruh Independensi Dewan Komisaris terhadap Kebijakan Dividen. Diponegoro Journal of Accounting.

Sholichah, W. A. (2015). Pengaruh Struktur Kepemilikan, Ukuran Perusahaan Dan Leverage Terhadap Nilai Perusahaan. Jurnal ILmu \& Riset Akuntansi.

Silalahi, U. (2017). Metode Penelitian Sosial. Bandung: PT Revika Aditama.

Simarmata, H. Y., \& Hutajulu, L. (2017). Pengaruh Profitability dan Investment Opportunity Set Terhadap Kebijakan Dividen dengan Likuiditas Sebagai Variabel Penguat. Jurnal Akuntansi dan Keuangan Daerah, 29-42.

Sugiyono. (2014). Metode Penelitian Kombinasi. Bandung: Alfabeta.
Sugiyono. (2015). Metode Penelitian Pendidikan: Pendekatan Kuantitatif, Kualitatif, dan $R$ \& D. Bandung: Alfabeta.

Suharli, M. (2007). Pengaruh Profitability dan Investment Opportunity Set Terhadap Kebijakan Dividen Tunai dengan Likuiditas Sebagai Variabel Penguat. Jurnal Ekonomi Akuntansi, 9-17.

Suryono, B. (2016). Analisis Rasio Keuangan dan Aplikasinya Terhadap Profitabilitas Perusahaan. Ekuitas (Jurnal Ekonomi Dan Keuangan). https://doi.org/10.24034/j25485024.y 1998.v2.i2.1862

Suwarti, T. (2010). Peran Likuiditas Sebagai Variabel Moderasi Hubungan Antara Profitabilitas dan Investment Opportunity Cost Terhadap Kebijakan Dividen.

Syafrida, \& Nurhayati, F. (2015). Analisis Penerapan Tax Amnesty di Indonesia dalam Rangka Meningkatkan Penerimaan Negara pada Sektor Perpajakan. Jurnal Ilmiah Universitas Bakrie.

Widayati, A. (2008). Staf Pengajar Jurusan Pendidikan Akuntansi - Universitas Negeri Yogyakarta 87. Jurnal Pendidikan Akuntansi Indonesia Vol. VI No. 1 Hal. 87 - 93.

Wirjolukito, A. Yanto, H., \& Sandy. (2003). Faktor-fator yang Merupakan Pertimbangan dalam Keputusan Pembagian Dividen: Tinjauan Terhadap Teori Persinyalan Dividen pada Perusahaan Go Public di Indonesia. Jurnal Ekonomi dan Bisnis. 
Jurnal Administrasi Bisnis (JAB)

Vol. 9. No. 3, 2019

(p-ISSN 2338-9605; e-2655-206X)

Zakiyah, T. (2017). Analisis konflik Agency Teory dan pengaruhnya terhadap kebijakan Dividen pada perusahaan yang tergabung dalam LQ 45 (Studi kasus tahun 2011-2015). Jurnal Ilmiah Akuntansi Dan Keuangan.

https://doi.org/10.32639/jiak.v6i1.124 